Research Article

\title{
The Development of Biomimetic Spherical Hydroxyapatite/Polyamide 66 Biocomposites as Bone Repair Materials
}

\author{
Xuesong Zhang, ${ }^{1}$ Ming Lu, ${ }^{1}$ Yan Wang, ${ }^{1}$ Xiaojing Su, ${ }^{1}$ and Xuelian Zhang ${ }^{2}$ \\ ${ }^{1}$ Department of Orthopaedics, Chinese People's Liberation Army General Hospital, Beijing 100853, China \\ ${ }^{2}$ Department of Endocrinology, China-Japan Friendship Hospital, Beijing 100029, China \\ Correspondence should be addressed to Xuelian Zhang; zhangxuelian66@sina.com
}

Received 28 February 2014; Accepted 21 May 2014; Published 6 July 2014

Academic Editor: Xiaoming Li

Copyright (C) 2014 Xuesong Zhang et al. This is an open access article distributed under the Creative Commons Attribution License, which permits unrestricted use, distribution, and reproduction in any medium, provided the original work is properly cited.

A novel biomedical material composed of spherical hydroxyapatite (s-HA) and polyamide 66 (PA) biocomposite (s-HA/PA) was prepared, and its composition, mechanical properties, and cytocompatibility were characterized and evaluated. The results showed that HA distributed uniformly in the s-HA/PA matrix. Strong molecule interactions and chemical bonds were presented between the s-HA and PA in the composites confirmed by IR and XRD. The composite had excellent compressive strength in the range between 95 and $132 \mathrm{MPa}$, close to that of natural bone. In vitro experiments showed the s-HA/PA composite could improve cell growth, proliferation, and differentiation. Therefore, the developed s-HA/PA composites in this study might be used for tissue engineering and bone repair.

\section{Introduction}

Hydroxyapatite (HA), with similar composition to natural bone, has been extensively developed for biomedical applications in the past decades because it has good biocompatibility and bioactivity and can bond with host bone directly [14]. However, HA ceramics devices, such as filler and porous scaffold, exhibit manifest brittleness, which vastly impedes its clinical applications.

In order to obtain a biomaterial with good bioactivity and good mechanical properties, more and more attention focuses on the researches and medical applications of a composite combining hydroxyapatite with a polymer because such composite possesses both good bioactivity (HA) and good ductility (polymer) [4-10]. Those biocomposites are biocompatible and osteoconductive and hence can bond with host bone directly and thus form a uniquely strong biomaterial-bone interface.

Previous studies have showed that the properties of HA have manifest effects on the properties of the HA/PA composites [11-16]. For example, HA with atom molar $\mathrm{Ca} / \mathrm{P}$ ratio of 1.67 is very stable and hence shows poor degradability and bioactivity in vivo while $\mathrm{HA}$ with lower atom molar $\mathrm{Ca} / \mathrm{P}$ ratio (form 1.5 to 1.67 ) exhibits higher solubility (degradability) and bioactivity. The size of HA also affects the properties of the obtained composite. A nanoscaled HA shows better bioactivity and enhancement effects on polymer and obtains higher mechanical properties compared to the microsized one because the nanosized HA have obvious surface effect and small size effect $[17,18]$.

Recently, nanohydroxyapatite (n-HA)/polyamide 66 biocomposites were developed by Sichuan University $[1,17]$. The composites were shown to have good mechanical strength similar to natural bone and good compatibility. Furthermore, cage and vertebral plate developed by those composites have been used for spine repair successfully [19]. However, nHA preparation process is very complex. Moreover, conglomeration of nanoparticles has been deemed to be one of the main obstacles in the preparation of polymer-based nanobiomaterials [20]. Hence, in this study, we prepared HA/PA composite composed of spherical HA with extrusion method, an industrialized method, and the composition, mechanical properties, and preliminary cell responses to the 
composites were investigated in order to assess the potential application as bone repair materials.

\section{Materials and Method}

2.1. Preparation of $s-H A / P A$. PA (BASF, A3K) and s-HA (provided by Sichuan University) were mixed proportionally and were processed by extrusion method according to the following parameters: extrusion temperature: $230-275^{\circ} \mathrm{C}$; main engine speed: $50 \mathrm{HZ}$; feed rate: $40 \mathrm{HZ}$.

S-HA/PA composites with $10 \mathrm{w} \%, 20 \mathrm{w} \%, 30 \mathrm{w} \%$, and $40 \mathrm{w} \% \mathrm{~s}-\mathrm{HA}$ content were prepared and named as 10HA/PA, 20HA/PA, 30HA/PA, and 40HA/PA, respectively.

2.2. IR, XRD, and Mechanical Strength. The composition and structure of the $30 \mathrm{HA} / \mathrm{PA}$ composite were characterized by Fourier transform infrared spectroscopy (170SX FT-IR Spectrometer; Nicolet, Madison, WI) and X-ray diffraction (X’Pert pro-MPD; Philips, Eindhoven, The Netherlands). To observe the S-HA distribution in PA matrices, the 30HA/PA composite was fractured in liquid nitrogen, and a crosssectional specimen was observed under a scanning electron microscope (Hitachi S-450). In addition, the effects of the amount of s-HA on the compressive strength of the composite were assessed in the composite samples $(\Phi 10 \times 12 \mathrm{~mm})$ containing different amounts of s-HA ( $0 \mathrm{wt} \%$, $10 \mathrm{wt} \%, 20 \mathrm{wt} \%, 30 \mathrm{wt} \%$, and $40 \mathrm{wt} \%)$ using a mechanical testing machine (REGER 30-50; Shenzhen Reger Co., Ltd., Shenzhen, China) with $50 \mathrm{kN}$ load cells. The cross-head speed was $5 \mathrm{~mm} /$ minute, and the load was applied until the specimens were compressed to about $20 \%$ of their original height. Five replicates were carried out for each group, and the results are expressed as the mean \pm standard deviation.

2.3. Cytocompatibility. Culture cells in a humidified atmosphere with $5 \% \mathrm{CO}_{2}$, MG63 osteoblast-like cells were cultured in Dulbecco's Modified Eagle Medium (DMEM) supplemented with $10 \%$ FBS plus $100 \mathrm{U} / \mathrm{mL}$ penicillin and $100 \mu \mathrm{g} / \mathrm{mL}$ streptomycin sulfate. Cells were incubated in $25 \mathrm{~cm}^{2}$ flasks to reach $80 \%$ confluence and then detached for further experiments. For all the cell culture experiments, $30 \mathrm{HA} / \mathrm{PA}$ composite samples with the size of $\Phi 12 \times 2 \mathrm{~mm}$ were used and MAC and tissue culture plate as controls. These samples were sonicated in ethanol and sterilized using ethylene oxide gas.

2.3.1. Cell Proliferation and Morphology. MG-63 osteoblastlike cells were cultured in DMEM supplemented with $10 \%$ FBS plus $100 \mathrm{U} / \mathrm{mL}$ penicillin and $100 \mu \mathrm{g} / \mathrm{mL}$ streptomycin sulfates at $37^{\circ} \mathrm{C}$ in a humidified $5 \% \mathrm{CO}_{2}$ atmosphere. Cells were incubated in $25 \mathrm{~cm}^{2}$ flasks to reach $80 \%$ confluence and then detached for further experiments. n-DA/MC composite scaffold samples with the size of $\Phi 6 \times 2 \mathrm{~mm}$ were used for all the cell culture experiments, and tissue culture plate (TCP) was used as a control. These samples were sonicated in ethanol and sterilized using ethylene oxide gas.
The proliferation of MG-63 cells on the scaffold samples was determined by using MTT (3-\{4,5-dimethylthiazol-2yl $\}$ 2,5-diphenyl-2H-tetrazolium-bromide) assay. MTT measures changes in absorbance at a specific wavelength and is widely used for measuring cell viability. The production of purple formazan in osteoblast cultures with or without the samples was measured after 1, 3, 5, and 7 days of incubation in 24-well culture plates. For this purpose, $100 \mu \mathrm{L}$ of MTT (MajorBiochem, Shanghai, China) solution $(5 \mathrm{mg} / \mathrm{mL})$ was added to each well (containing either cells alone or pellets with adherent cells removed from the original culturing well) and the cells were incubated for 4 hours. Subsequently, the culture medium was aspirated and dimethyl sulfoxide $1000 \mu \mathrm{L} /$ well was added to dissolve the formazan completely for 10 minutes at $37^{\circ} \mathrm{C}$. Then $100 \mu \mathrm{L}$ of solution was transferred to a 96-well enzyme-linked immunosorbent assay plate and the absorbance was measured at $490 \mathrm{~nm}$ using a microplate reader (Multiskan MK3, Thermo Electron Corporation, Waltham, MA). Phase contrast microscopy was used to observe the cell morphology.

2.3.2. ALP Activity. MG-63 cells were seeded on the samples and ALP activity of cells was measured at 1, 3, 5, and 7 days, and the culture medium in 24-well plates was aspirated. $200 \mu \mathrm{L}, 1 \%$ Nonidet P-40 (NP-40) solution was added to each well at room temperature (RT) and incubated for 1 hour. The cell lysate was obtained and centrifuged. $50 \mu \mathrm{L}$ supernatant and $50 \mu \mathrm{L} 2 \mathrm{mg} / \mathrm{mL}$ p-nitrophenylphosphate (Sangon, Shanghai, China) substrate solution composed of $0.1 \mathrm{~mol} / \mathrm{L}$ glycine, $1 \mathrm{mmol} / \mathrm{L} \mathrm{MgCl}_{2} \cdot 6 \mathrm{H}_{2} \mathrm{O}$ were added to 96 -well plates and incubated for $30 \mathrm{~min}$ at $37^{\circ} \mathrm{C}$. The reaction was quenched by addition of $100 \mu \mathrm{L}, 0.1 \mathrm{~N} \mathrm{NaOH}$; the absorbance of ALP was quantified at the wavelength of $405 \mathrm{~nm}$ using a microplate reader (SPECTRAmax 384, Molecular Devices, USA). The total protein content in cell lysate was determined using the bicinchoninic acid (BCA) method in aliquots of the same samples with the Pierce protein assay kit (Pierce Biotechnology Inc., Rockford, IL), read at $560 \mathrm{~nm}$, and calculated according to a series of albumin (BSA) standards. The ALP levels were normalized to the total protein content at the end of the experiment.

\section{Results}

3.1. IR and XRD. Figure 1(a) showed the characteristic peaks of the PA. The $-\mathrm{CO}-\mathrm{NH}-$ peaks could be observed at about $1556 \mathrm{~cm}^{-1}, 3307 \mathrm{~cm}^{-1}$ (N-H stretching), and $1642 \mathrm{~cm}^{-1}$ $(\mathrm{C}=\mathrm{O})$. Bonds at 2857 and $2925 \mathrm{~cm}^{-1}$ were the characteristic peaks of $\mathrm{C}-\mathrm{H}$ vibration. In Figure $1(\mathrm{~b})$, the $\mathrm{PO}_{4}{ }^{3-}$ peaks were found at about 566, 953,1033, and $1107 \mathrm{~cm}^{-1}$. The $\mathrm{OH}$ - peaks were found at about 3569 and $605 \mathrm{~cm}^{-1}$. Figure 1(c) was the spectra of composite. It can be seen that peaks of both sHA and PA presented in the composite, and the peaks had shown clear shifts. The peaks of PA shifted from 1556, 1642, and $3307 \mathrm{~cm}^{-1}$ to 1552,1637 , and $3301 \mathrm{~cm}^{-1}$. Owing to the existence of hydrogen, it will absorb more energy than before, resulting in the absorption wavelength getting shorter. So, 


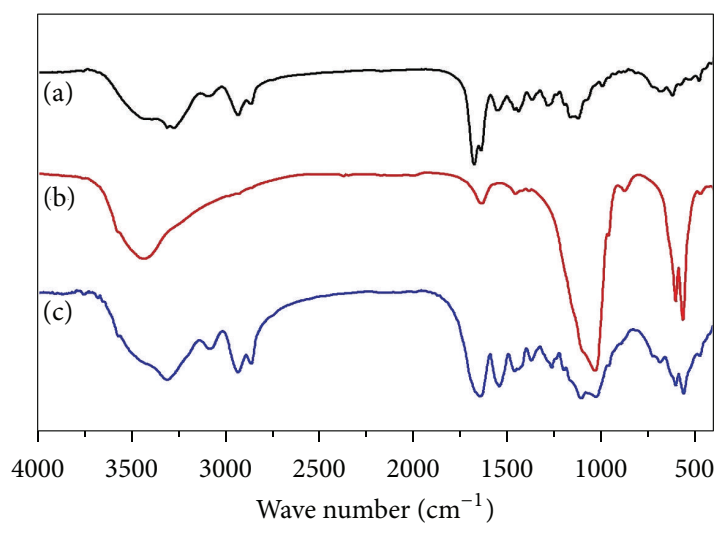

FIgURE 1: FT-IR spectra of PA (a), s-HA (b), and s-HA/PA composite (c).

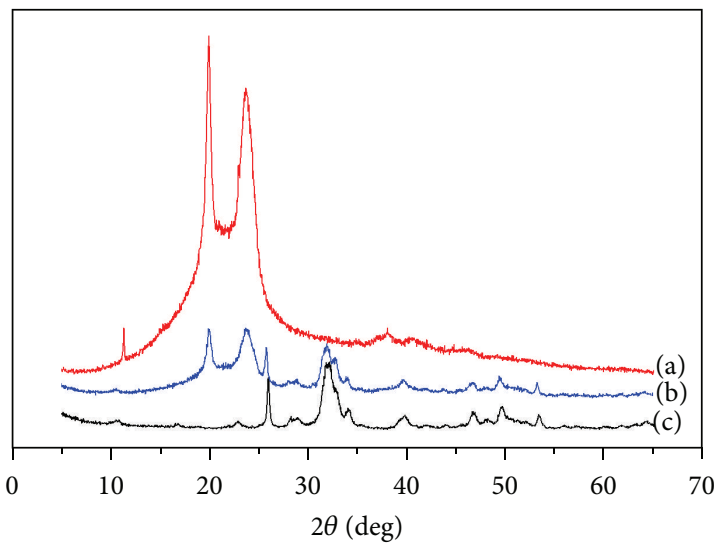

FIgure 2: The XRD patterns of PA (a), s-HA/PA composite (b), and s-HA (c).

the peaks of HA shifted from 3569 to $3561 \mathrm{~cm}^{-1}$. Those peaks' shift suggests that hydrogen formed between s-HA and PA.

Figure 2 showed the XRD patterns of PA (a), s-HA/PA composite (b), and s-HA (c). Figure 2(c) indicated that the major characteristic peaks of HA appeared around $25.9^{\circ}, 32^{\circ}$, $33^{\circ}, 33.9^{\circ}$, and $39.7^{\circ}$, which were corresponding to the peaks of the bone apatite [5]. Two strong peaks at $2 \theta=19.9^{\circ}$, $23.5^{\circ}$ were attributed to PA in Figure 2(a). Because of the interaction of HA and copolymer, the orderliness of PA was seriously disturbed, which is responsible for the decrease of the intensities of PA peaks in Figure 2(b).

3.2. Compressive Strength of $s-H A / P A$ Composite. The compressive strength of composite with different s-HA is shown in Table 1. It can be seen that the compressive strength increased from $67 \mathrm{MPa}$ to $132 \mathrm{MPa}$ with the increase of s-HA from 0 to $40 \%$ in composite.

3.3. SEM Analysis. The SEM photographs of s-HA and sHA/PA composite are shown in Figure 3 . The s-HA was about 20-60 $\mu \mathrm{m}$ (Figure 3(a)) and uniformly distributed in PA matrix (Figure 3(b)). In addition, no cracks between s-HA and PA were observed.
TABLE 1: Compressive strength of s-HA/PA composite.

\begin{tabular}{lc}
\hline Samples & $\begin{array}{c}\text { Compression strength }(\mathrm{MPa}) \\
\text { mean } \pm \text { SD }\end{array}$ \\
\hline PA & $67 \pm 7$ \\
$10 \mathrm{HA} / \mathrm{PA}$ & $95 \pm 15$ \\
$20 \mathrm{HA} / \mathrm{PA}$ & $108 \pm 9$ \\
$30 \mathrm{HA} / \mathrm{PA}$ & $126 \pm 8$ \\
$40 \mathrm{HA} / \mathrm{PA}$ & $132 \pm 11$ \\
\hline
\end{tabular}

\subsection{Cytocompatibility}

3.4.1. Cell Proliferation. The optical density (OD) values can provide an indicator of cell viability on biomaterials; thus the proliferation of MG63 cells on 30HA/PA composite was evaluated using MTT. As shown in Figure 4, the OD values of the composite and the controls (tissue culture plate, TCP) increased with time, suggesting that MG63 cells were viable on these samples, showing positive cellular responses. No significant difference for OD values was found between the composite and controls at 1,3 , and 5 days. However, the OD value of the composite was higher than those of control at 7 days, indicating that the $30 \mathrm{HA} / \mathrm{PA}$ composite could promote cell proliferation at 7 days.

3.4.2. ALP Activity. ALP activity of MG63 cells cultured on the 30HA/PA composite was determined at 1, 3,5, and 7 days. The results are shown in Figure 5. The ALP activity increased with time for both the composite and TCP. No significant difference between the composite and TCP was found at 1 and 3 days. However, the level of ALP activity of cells on the HA/PA composite was obviously higher than those of MAC and tissue culture plate at 5 and 7 days.

3.4.3. Cell Morphology. The phase contrast microscopy images of MG63 cells cultured with the HA/PA composite scaffolds are shown in Figure 6. It can be seen that, after 1 day of culture, the cells had a sheet shape and there were large intercellular spaces. After 3 days, the population of the cells increased and the intercellular spaces reduced manifestly. The cells kept increasing and the gap between cells disappeared after 5 and 7 days, indicating that the HA/PA composite scaffolds had no negative effects on cells growth and maintain normal cell morphology.

\section{Discussion}

HA has an inorganic component similar to that in human hard tissue. It has a good biocompatibility and can bond to bone tissue in body $[1,21]$. The outstanding biological performance of HA biomaterial has been widely proved in the forms of bone filler, coating on titanium alloy, and recently as scaffolds for cell carrier in bone tissue engineering $[1,5$, $9,11]$. So, HA is a good candidate for the preparation of ceramic/polymer composites. Previous studies have reported many performances of $\mathrm{HA}$; for example, size and $\mathrm{Ca} / \mathrm{P}$ ratio exhibited manifest effects on the properties of the resultant 


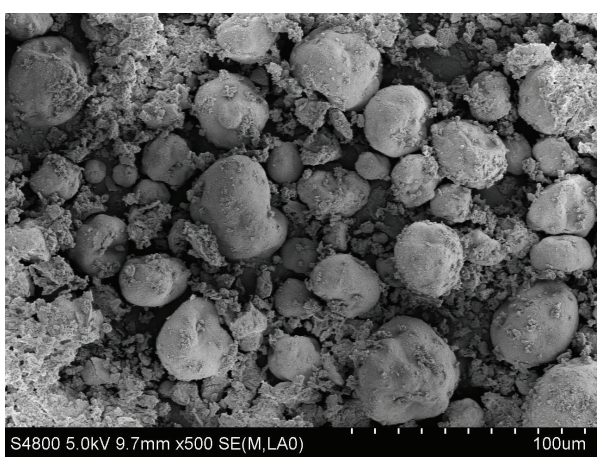

(a)

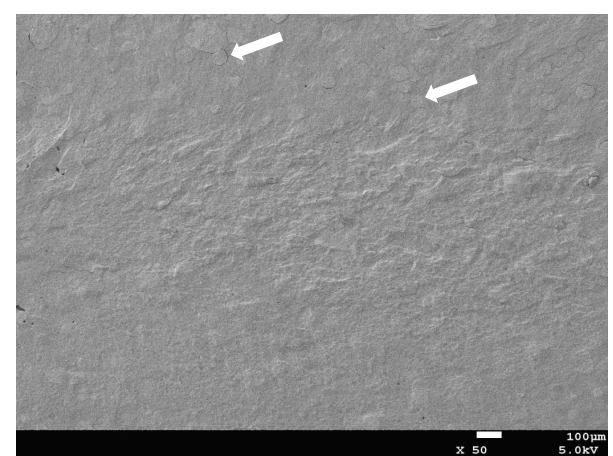

(b)

FIgURE 3: The morphology of s-HA (a) and s-HA/PA (b).

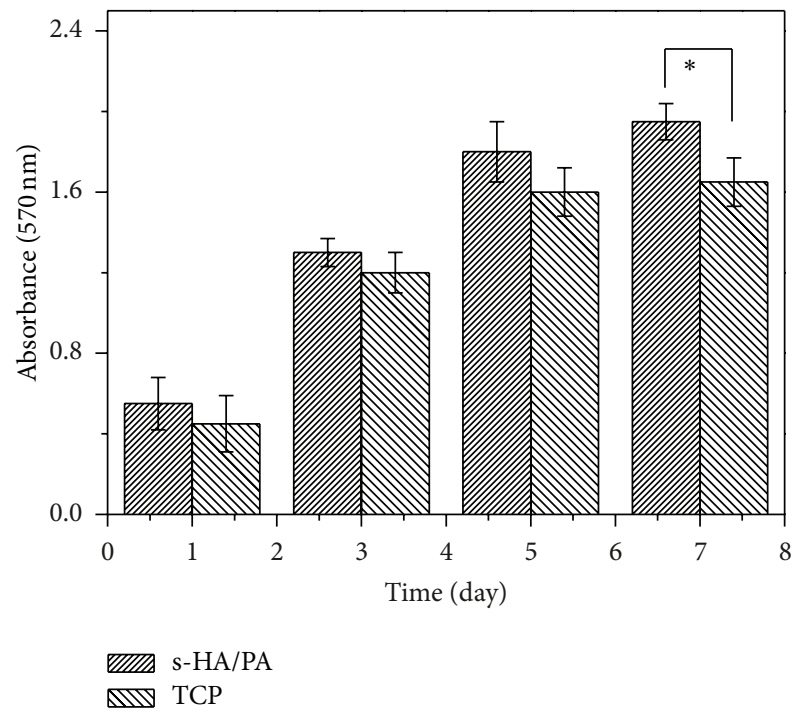

FIGURE 4: Viability of MG63 cells on s-HA/PA composite by MTT assay, TCP as controls, ${ }^{*} P<0.05$.

composite [22]. Hence, in this study, the spherical HA was used as inorganic phase to enhance polyamide 66 to obtain novel composites, and their properties were characterized. It was shown by IR and XRD that chemical bond was formed between s-HA and PA, which was considered to be a strong interface bond. So when the s-HA are imposed with external pressure, the pressure could be transferred into PA via chemical bond, thus improving the whole mechanical strength. The interface interactions between the polymer and inorganic mineral have been proved to have positive effects on the mechanical properties and the distribution of inorganic particles into the composites [23-25].

In this study, the prepared s-HA/PA composite has a good homogeneity (Figure 3). Furthermore, no obvious interface debonding could be observed in the fracture surface of composite, suggesting that there was a good interface between sHA and PA, which was consistent with the results of IR and XRD.

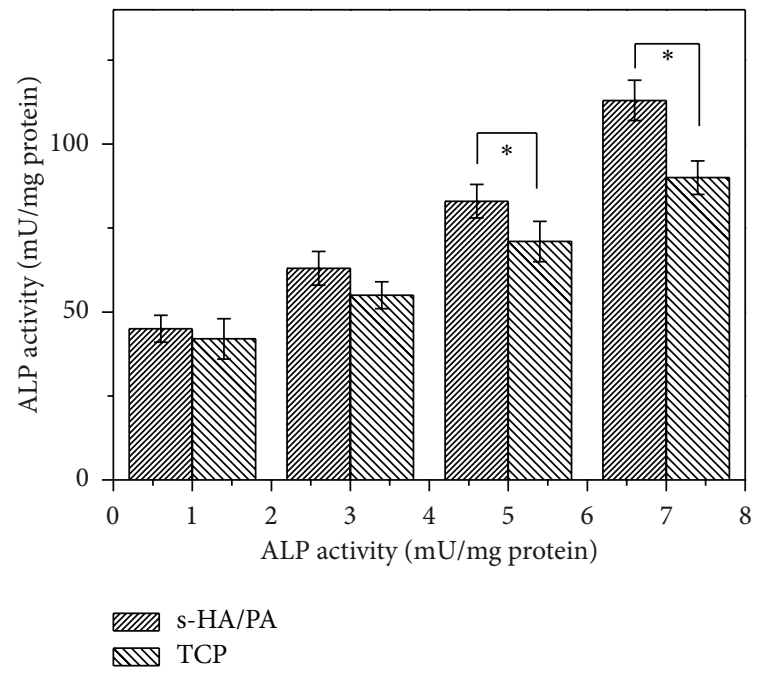

FIGURE 5: ALP activity of MG63 cells cultured on s-HA/PA composite, TCP as controls, ${ }^{*} P<0.05$.

The compressive strength of the composites with 10$40 \mathrm{w} \%$ s-HA content ranged between 95 and $132 \mathrm{MPa}$, which was close to that of the natural bone, between 50 and $140 \mathrm{MPa}$ [26]. It has been reported that n-HA/PA composite showed good mechanical strength and could meet the fundamental requirements for supporting after implantation [1]. Compared to that, s-HA/PA composites showed higher compressive strength. Therefore, s-HA/PA should have enough compressive strength for the support requirements in vivo.

To evaluate the in vitro biocompatibility of biomaterials, the cell culture experiments are useful approaches [27, 28]. In this study, the MG63 cells were used to test the cytocompatibility of the s-HA/PA composite. The results showed that the MG63 cells could proliferate better on the composites, as was demonstrated by the MTT assay, suggesting positive cellular responses to this material. After 7-day culture, the $\mathrm{OD}$ values of the composites were significantly higher than those of TCP, indicating that the composites could promote the cell proliferation better and had higher cytocompatibility than TCP. The phase contrast microscopy results exhibited 


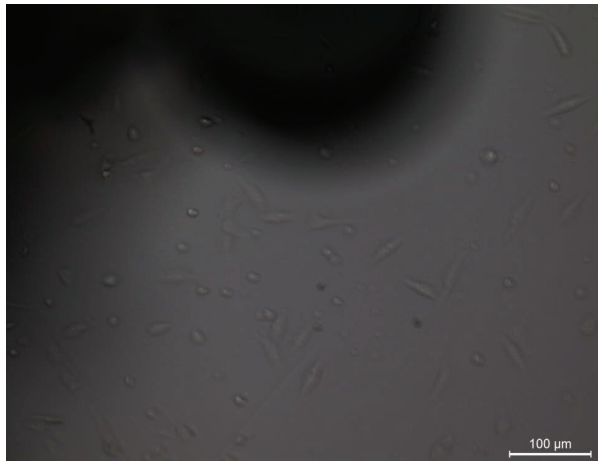

(a)

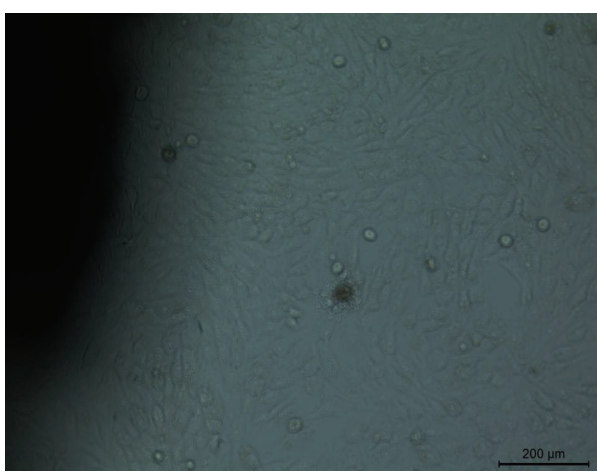

(c)

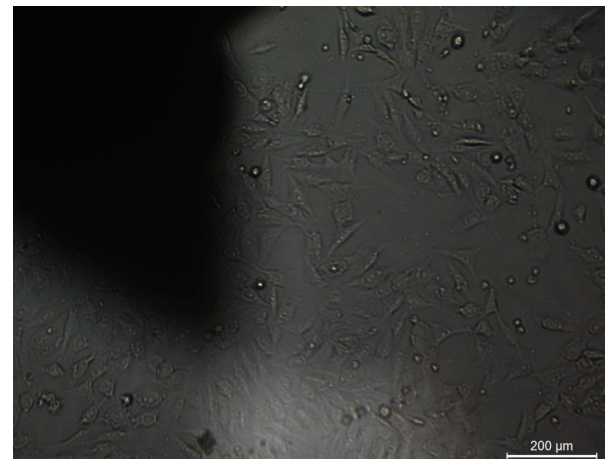

(b)

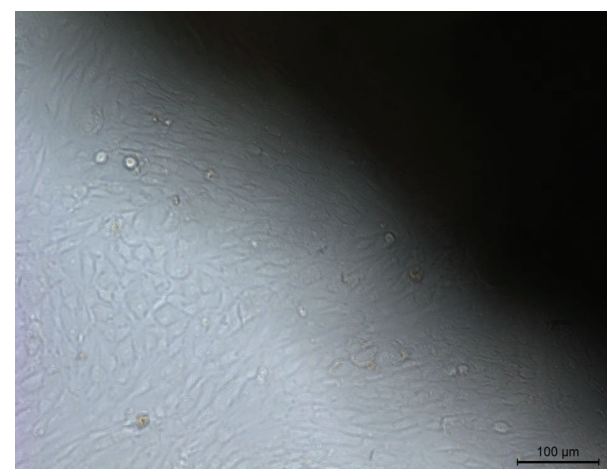

(d)

Figure 6: Phase contrast microscopy images of MG63 cells cultured on the s-HA/PA composite for 1 day (a), 3 days (b), 5 days (c), and 7 days (d).

that cells population increased with high speed and the spaces among the cells disappeared at 5 days and that the cells maintain normal morphology, suggesting that the s-HA/PA composites had no negative effect on the cell attachment and proliferation. Furthermore, the ALP activity has been used as an early marker for functionality and differentiation of osteoblasts during in vitro experiments [29-33]. The results showed that the ALP of the MG63 cells cultured on the sHA/PA composites exhibited significantly higher levels of expression than that of the cells cultured on TCP at 5 and 7 days, indicating that the composite could induce better the differentiation of the cell into osteogenic cells.

\section{Conclusion}

Novel s-HA/PA biocomposites were prepared by extrusion method in this study. The s-HA was homogenously distributed into HA/PA matrix and chemical bond was formed at the interface between organic phase and inorganic phase. The compressive strength of composite was close to that of natural bone. Furthermore, the s-HA/PA composites could not only promote cell proliferation but also induce the differentiation of the cell into osteogenic cells. The results indicated that the s-HA/PA biocomposite might be a candidate for bone repair material.

\section{Conflict of Interests}

The authors declare that there is no conflict of interests regarding the publication of this paper.

\section{References}

[1] H. Wang, Y. Li, Y. Zuo, J. Li, S. Ma, and L. Cheng, "Biocompatibility and osteogenesis of biomimetic nano-hydroxyapatite/ polyamide composite scaffolds for bone tissue engineering," Biomaterials, vol. 28, no. 22, pp. 3338-3348, 2007.

[2] X. Li, Q. Feng, X. Liu, W. Dong, and F. Cui, "Collagen-based implants reinforced by chitin fibres in a goat shank bone defect model," Biomaterials, vol. 27, no. 9, pp. 1917-1923, 2006.

[3] B. Chang, C. K. Lee, K. S. Hong et al., "Osteoconduction at porous hydroxyapatite with various pore configurations," Biomaterials, vol. 21, no. 12, pp. 1291-1298, 2000.

[4] A. Hanifi and F. M. Hossein, "Bioresorbability evaluation of hydroxyapatite nanopowders in a stimulated body fluid medium," Iranian Journal of Pharmaceutical Sciences, vol. 4, no. 2, pp. 141-148, 2008.

[5] X. Li, L. Wang, Y. Fan, Q. Feng, F. Cui, and F. Watari, "Nanostructured scaffolds for bone tissue engineering," Journal of Biomedical Materials Research A, vol. 101A, no. 8, pp. 24242435, 2013.

[6] P. Shokrollahi, H. Mirzadeh, O. A. Scherman, and W. T. S. Huck, "Biological and mechanical properties of novel composites based on supramolecular polycaprolactone and functionalized 
hydroxyapatite," Journal of Biomedical Materials Research A, vol. 95, no. 1, pp. 209-221, 2010.

[7] C. L. Dai, C. S. Liu, J. Wei, H. Hong, and Q. Zhao, "Molecular imprinted macroporous chitosan coated mesoporous silica xerogels for hemorrhage control," Biomaterials, vol. 31, no. 30, pp. 7620-7630, 2010.

[8] X. Li, H. Liu, X. Niu et al., "The use of carbon nanotubes to induce osteogenic differentiation of human adipose-derived MSCs in vitro and ectopic bone formation in vivo," Biomaterials, vol. 33, no. 19, pp. 4818-4827, 2012.

[9] I. Armentano, M. Dottori, E. Fortunati, S. Mattioli, and J. M. Kenny, "Biodegradable polymer matrix nanocomposites for tissue engineering: a review," Polymer Degradation and Stability, vol. 95, no. 11, pp. 2126-2146, 2010.

[10] K. E. Tanner, "Bioactive composites for bone tissue engineering," Proceedings of the Institution of Mechanical Engineers $H$ : Journal of Engineering in Medicine, vol. 224, no. 12, pp. 13591372, 2010.

[11] R. Z. Legeros, S. Lin, R. Rohanizadeh, D. Mijares, and J. P. Legeros, "Biphasic calcium phosphate bioceramics: preparation, properties and applications," Journal of Materials Science: Materials in Medicine, vol. 14, no. 3, pp. 201-209, 2003.

[12] X. Li, Y. Yang, Y. Fan, Q. Feng, F. Cui, and F. Watari, "Biocomposites reinforced by fibers or tubes as scaffolds for tissue engineering or regenerative medicine," Journal of Biomedical Materials Research A, vol. 102, pp. 1580-1594, 2014.

[13] H. Guo, J. C. Su, J. Wei, H. Kong, and C. Liu, "Biocompatibility and osteogenicity of degradable Ca-deficient hydroxyapatite scaffolds from calcium phosphate cement for bone tissue engineering," Acta Biomaterialia, vol. 5, no. 1, pp. 268-278, 2009.

[14] J. H. C. Lin, K. H. Kuo, S. J. Ding, and C. P. Ju, "Surface reaction of stoichiometric and calcium-deficient hvdroxyapatite in simulated body fluid," Journal of Materials Science: Materials in Medicine, vol. 12, no. 8, pp. 731-741, 2001.

[15] X. Li, C. A. van Blitterswijk, Q. Feng, F. Cui, and F. Watari, “The effect of calcium phosphate microstructure on bone-related cells in vitro," Biomaterials, vol. 29, no. 23, pp. 3306-3316, 2008.

[16] Y. E. Greish, "Phase evolution during the low temperature formation of calcium-deficient hydroxyapatite-gypsum composites," Ceramics International, vol. 37, no. 5, pp. 1493-1500, 2011.

[17] X. Zhang, Y. B. Li, Z. M. Song, Y. Zuo, and Y. H. Mu, "A study on the mechanical properties of PA66/ HA composites," China Plastics, vol. 19, pp. 25-29, 2005.

[18] X. M. Li, H. F. Liu, X. F. Niu et al., "Osteogenic differentiation of human adipose-derived stem cells induced by osteoinductive calcium phosphate ceramics," Journal of Biomedical Materials Research B: Applied Biomaterials, vol. 97, no. 1, pp. 10-19, 2011.

[19] X. Yang, Q. Chen, L. Liu et al., "Comparison of anterior cervical fusion by titanium mesh cage versus nano-hydroxyapatite/polyamide cage following single-level corpectomy," International Orthopaedics, vol. 37, no. 12, pp. 2421-2427, 2013.

[20] X. Li, H. Gao, M. Uo et al., "Effect of carbon nanotubes on cellular functions in vitro," Journal of Biomedical Materials Research A, vol. 91, no. 1, pp. 132-139, 2009.

[21] X. Liu, X. Li, Y. Fan et al., "Repairing goat tibia segmental bone defect using scaffold cultured with mesenchymal stem cells," Journal of Biomedical Materials Research B: Applied Biomaterials, vol. 94, no. 1, pp. 44-52, 2010.
[22] X. Wang, Y. Li, J. Wei, and K. De Groot, "Development of biomimetic nano-hydroxyapatite/poly(hexamethylene adipamide) composites," Biomaterials, vol. 23, no. 24, pp. 47874791, 2002.

[23] W. Jie and L. Yubao, "Tissue engineering scaffold material of nano-apatite crystals and polyamide composite," European Polymer Journal, vol. 40, no. 3, pp. 509-515, 2004.

[24] X. Li, L. Wang, Y. Fan, Q. Feng, and F. Cui, "Biocompatibility and toxicity of nanoparticles and nanotubes," Journal of Nanomaterials, vol. 2012, Article ID 548389, 19 pages, 2012.

[25] J. Wei, S. J. Heo, D. H. Kim, S. E. Kim, Y. T. Hyun, and J. Shin, "Comparison of physical, chemical and cellular responses to nano- and micro-sized calcium silicate/poly( $\varepsilon$-caprolactone) bioactive composites," Journal of the Royal Society Interface, vol. 5, no. 23, pp. 617-630, 2008.

[26] C. C. P. M. Verheyen, J. R. De Wijn, C. A. Van Blitterswijk, and K. De Groot, "Evaluation of hydroxylapatite/poly(L-lactide) composites: mechanical behavior," Journal of Biomedical Materials Research, vol. 26, no. 10, pp. 1277-1296, 1992.

[27] K. Leja and G. Lewandowicz, "Polymer biodegradation and biodegradable polymers-a review," Polish Journal of Environmental Studies, vol. 19, no. 2, pp. 255-266, 2010.

[28] X. Li, X. Liu, W. Dong et al., "In vitro evaluation of porous poly(L-lactic acid) scaffold reinforced by chitin fibers," Journal of Biomedical Materials Research B Applied Biomaterials, vol. 90, no. 2, pp. 503-509, 2009.

[29] L. M. Havill, J. Rogers, L. A. Cox, and M. C. Mahaney, "QTL with pleiotropic effects on serum levels of bone-specific alkaline phosphatase and osteocalcin maps to the baboon ortholog of human chromosome 6p23-21.3," Journal of Bone and Mineral Research, vol. 21, no. 12, pp. 1888-1896, 2006.

[30] Q. Li, K. Yu, X. Tian et al., "17beta-Estradiol overcomes human myeloma RPMI8226 cell suppression of growth, ALP activity, and mineralization in rat osteoblasts and improves RANKL/OPG balance in vitro," Leukemia Research, vol. 33, no. 9, pp. 1266-1271, 2009.

[31] X. M. Li, Y. Huang, L. S. Zheng et al., "Effect of substrate stiffness on the functions of rat bone marrow and adipose tissue derived mesenchymal stem cells in vitro," Journal of Biomedical Materials Research A, vol. 102, no. 4, pp. 1092-1101, 2014.

[32] A. J. Dulgar-Tulloch, R. Bizios, and R. W. Siegel, "Human mesenchymal stem cell adhesion and proliferation in response to ceramic chemistry and nanoscale topography," Journal of Biomedical Materials Research A, vol. 90, no. 2, pp. 586-594, 2009.

[33] N. Ribeiro, S. R. Sousa, and F. J. Monteiro, "Influence of crystallite size of nanophased hydroxyapatite on fibronectin and osteonectin adsorption and on MC3T3-E1 osteoblast adhesion and morphology," Journal of Colloid and Interface Science, vol. 351, no. 2, pp. 398-406, 2010. 

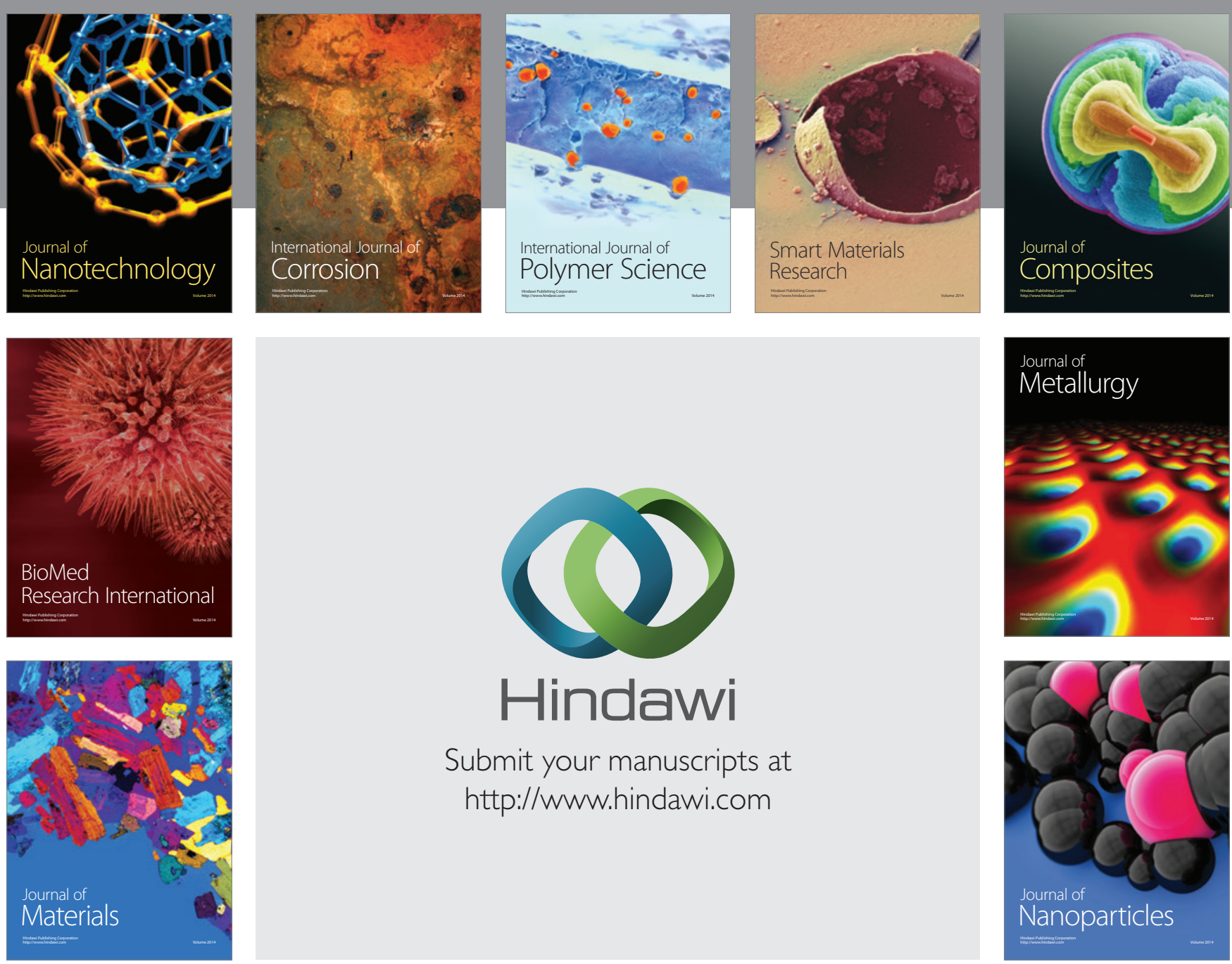

Submit your manuscripts at http://www.hindawi.com
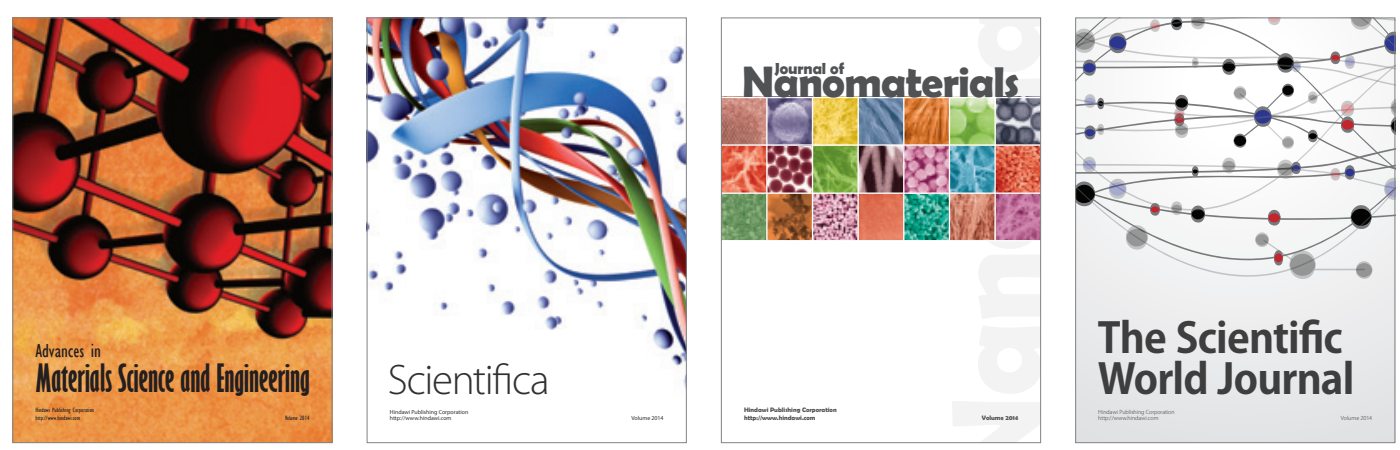

\section{The Scientific World Journal}
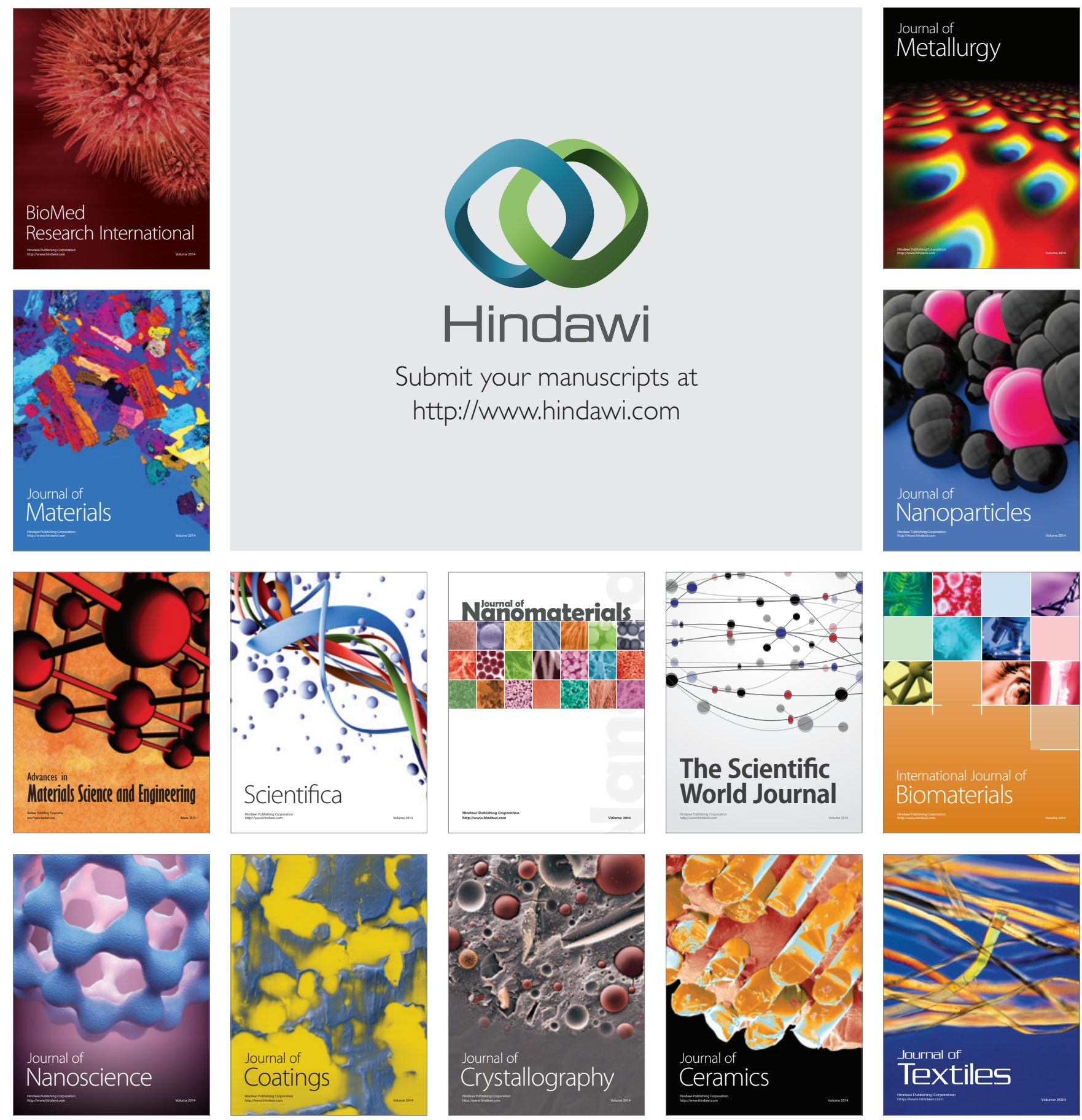